\title{
Annual dynamics of shortwave radiation of bare arable lands on a global scale incorporating their roughness
}

\author{
Jerzy Cierniewski ${ }^{1}$ iD $\cdot$ Jakub Ceglarek ${ }^{1}$
}

Received: 18 May 2018 / Accepted: 12 November 2018 / Published online: 24 November 2018

(c) The Author(s) 2018

\begin{abstract}
Smoothing soil surfaces, which had previously been deeply plowed, increases their albedo, which results in a lower amount of shortwave radiation being absorbed by their surface layer. Those surfaces emit less long-wave radiation too, leading to a reduction in their surface temperature, which can affect the climate. This paper quantitatively estimates the highest possible amount of shortwave radiation that could be reflected throughout the year from bare soils on arable land in the most extensive agricultural regions, where major crops are cultivated, on six of the Earth's continents. The estimation refers to the highest levels of soil radiation occurring during clear-sky conditions without any clouds when the surfaces that had been conventionally tilled were bare for several days or more after the day of planting and were air-dried in two extreme roughness states: those formed by a plow and a smoothing harrow. The annual dynamics of reflective shortwave radiation of the bare soils were obtained using vectorized and rasterized geostatistical data sets about the areas of the soils and periods when they were bare, as well the spectra of the soil units that occupied the majority of these areas. Adding together all of the diurnal amounts of shortwave radiation reflected from the bare soils for each of the regions in the world, it was found that their radiation peak, appearing on the 140th days of the year, can reach about $22 \mathrm{EJ} /$ day for soils treated by a plow, and a further $3 \mathrm{EJ} /$ day when they are smoothed by a smoothing harrow.
\end{abstract}

Keywords Annual variations $\cdot$ Bare soil albedo $\cdot$ Shortwave radiation $\cdot$ Soil roughness

\section{Introduction}

Arable lands, according to the meaning of the Latin word "arabilis" as capable of being plowed (Oxford English Dictionary 2013), are discussed in this study as the Earth's land surfaces which are treated by a plow and other agricultural tools for growing crops. These surfaces resulting from human activity consist of two components: bare soils and crops with different reflectance of incident solar reflective spectrum in the range of $0.3-3 \mu \mathrm{m}$. Soils show a gradual increase in their reflectance in the visible and near-infrared with increasing wavelength, up to around $1.4 \mu \mathrm{m}$. Meanwhile, crops during the growing seasons at the beginning of the near-infrared range display a sharp increase in reflectance. The reflectance of both the components in the further range of the spectrum $(1.4-3 \mu \mathrm{m})$ remains unchanged or

Jerzy Cierniewski

ciernje@amu.edu.pl

1 Department of Soil Science and Remote Sensing of Soils, Adam Mickiewicz University in Poznań, Poznan, Poland gradually decreases. The difference between spectral reflectance of soils and crops affects the reflectance of arable lands as whole objects comprising these two components. Rechid et al. (2005) reported that an increasing share of crop cover increased the broadband blue-sky albedo $(\alpha)$ of arable fields with dark-colored soils. $\alpha$ defines the ratio of the amount of radiance reflected by a surface to the incident upon it, the direct solar irradiance and diffuse irradiance scattered by the atmosphere in the entire solar reflective spectrum. The upwelling and down welling radiations are integrated over the whole hemisphere across a given wavelength range (usually visible) (Martonchik et al. 2000; Schaepman-Strub et al. 2006). The overall $\alpha$ level of the arable lands with dark-colored soils in mid-latitudes in the spring, after the snow has melted and before vegetation emerges, is about 0.05-0.15 (Oke 1987; Dobos 2017). Baumgardner et al. (1986) reported that the $\alpha$ level of arable land with crop cover lower than $15 \%$ was like $\alpha$ of bare soils on which crops were growing. When the cover was between 15 and $40 \%, \alpha$ of the arable lands was controlled by both of their components, the soil and the crops, and when the cover was 
above $40 \%$, mainly by the crops. During the growing season, with the maturation of crops such as cereals, with increasing height and leaf area, the overall $\alpha$ level of the land increases to around 0.25 , and when the cereals finally mature to harvest, $\alpha$ of the land increases again (Dexter 2004; Song 1999). The $\alpha$ level of arable lands with light-colored soils, from the moment when crops have not germinated, yet until their area is completely covered by the crops, can decrease from about $0.4-0.35$ to 0.25 .

Arable lands in conventional tillage are uncovered with crops when their surfaces are being prepared for the sowing of cultivated plants or after the plants have been harvested. The overall $\alpha$ level of bare soils is mostly determined by the contents of soil pigments, such as soil organic matter (SOM) (Obukhov and Orlov 1964), carbonates $\left(\mathrm{CaCO}_{3}\right)$, and iron oxides $\left(\mathrm{Fe}_{2} \mathrm{O}_{3}\right)$ (Mikhaylova and Orlov 1986). The higher the content of SOM and $\mathrm{Fe}_{2} \mathrm{O}_{3}$, and the lower content of $\mathrm{CaCO}_{3}$, the lower the $\alpha$ level. Cierniewski et al. (2017) used examples of different soils studied in Poland and Israel to show that their overall $\alpha$ level can be sufficiently accurately predicted by their $\mathrm{SOM}$ and $\mathrm{CaCO}_{3}$ content, also taking into account the state of their roughness.

The contents of the aforementioned soil pigments are soil properties, which remain fairly constant, in contrast to the roughness and moisture of cultivated soil surfaces, which are treated as the most dynamically changing soil properties. In general, an increase in soil-surface moisture causes a decrease in the overall $\alpha$ level. If the soil water content decreases from the full saturation to the field capacity (FC), the $\alpha$ level does not change or decreases slightly (Cierniewski 1993; Music and Pelletier 1986; Vinogradov 1983). The most dramatic increase in the $\alpha$ level appears when the water content decreases from the FC to the hygroscopic capacity (HC). If the decrease in water content is continued below HC, the increase in $\alpha$ becomes slight or unnoticeable (Baumgardner et al. 1986; Idso et al. 1975). However, it should be emphasized some soil surfaces, especially those not developed from heavy materials, where the groundwater table is not shallow underneath quickly dry out after rain events, reaching the air-dry moisture state and increasing their overall $\alpha$ level.

The roughness of soil surfaces has a similarly strong effect on their overall $\alpha$ level as the effect of their surface moisture. This influence depends on the illumination conditions described by the solar zenith angle $\left(\theta_{\mathrm{s}}\right)$, the proportion of the diffuse radiance, and the cloud cover. In clear-sky conditions, i.e., without any clouds, $\alpha$ of bare soils, as well as other natural and man-made objects due to the irregularity of their surfaces, increases with increasing $\theta_{\mathrm{s}}$. As early as the 1960 s, Monteith and Szeice (1961) reported that $\alpha$ of bare soil increased in the afternoon from 0.16 to 0.19 , while $\theta_{\mathrm{s}}$ increased from $30^{\circ}$ to $70^{\circ}$. Kondratyev (1969) noticed that, in the morning, when $\theta_{\mathrm{s}}$ decreased from $80^{\circ}$ to $25^{\circ}, \alpha$ of dry stony and loamy soils decreased from 0.22 to 0.11 and from 0.34 to 0.17 , respectively. Pinty et al. (1989) and Oguntunde et al. (2006) also reported an increase in the narrowband and broadband albedo of cultivated soils. Bare soil $\alpha$ achieves its lowest value at local solar noontime when $\theta_{\mathrm{s}}$ reaches its minimum. Meanwhile, the highest $\alpha$ value, approximately 1 , is observed at sunrise and sunset. If the diurnal $\alpha$ variation is plotted against $\theta_{\mathrm{s}}$, it shows a characteristic U-shaped curve (Roxy et al. 2010). Sometimes, the curve is asymmetrical around solar noon due to the formation of dew or changes in weather conditions during the day. The higher the proportion of the diffuse radiation component, that is also the effect of greater cloud cover, the weaker the influence of the $\theta_{\mathrm{s}}$ variation on $\alpha$ of these objects.

The spectral reflectance of bare soils increases with a decrease in irregularities (Bowers and Hanks 1965; Orlov 1966; Piech and Walker 1974). Reducing the size of soil aggregates and clods results in increasing the spectral reflectance of soils. Larger aggregates, less regular and spherical in shape, with deeper spaces between them, absorb more of the reflective radiation reaching them than smaller aggregates with more rounded shapes and shallower spaces between them (Mikhaylova and Orlov 1986). The irradiation is reflected multiple times between these aggregates and clods. When their size decreases, the probability of radiation absorption decreases (Coulson and Reynolds 1971).

The roughness of soils refers to their irregular surfaces composed of soil particles, aggregates, clods and stones of various sizes, and their directional and non-directional spread (with random distributions), creating a specific microrelief configuration of arable lands formed by agricultural tools. Decades ago, variations in soil-surface height could only be measured in one direction using a profile meter with needles or a chain set (Gilley and Kottwitz 1995). Nowadays, the variation can be automatically recorded using laser scanners along single or multiple straight lines, allowing the analysis of soil-surface irregularities with about $1 \mathrm{~mm}$ horizontal and vertical spatial resolutions in a two-dimensional or three-dimensional space, respectively (Thomsen et al. 2015). Recently, the analysis of soil roughness in the three-dimensional space has been based on methods that use photographs of the studied soil surface taken from over a dozen directions using a digital camera which is either handheld or attached to a monopod that moves around the area of interest (Heng et al. 2010; Rieke-Zapp and Nearing 2005; Gilliot et al. 2017). These methods allow for the creation of digital elevation models (DEMs) of the studied surfaces, which are the basis for calculating the roughness indices of soil surfaces. The height standard deviation (HSD) is the most common index for describing the soil-surface roughness (Ulaby et al. 1982; Marzahn et al. 2012). Boiffin (1986) proposed the use of the turtle index, which expresses the ratio between the actual length of the soil-surface profile 
and the projected horizontal length of this profile. Later, Taconet and Ciarletti (2007) modified the reference of the index to a two-dimensional space, defining it $\left(T_{3 \mathrm{D}}\right)$ as the ratio of the real surface area within its basic DEM unit to its flat horizontal area.

Cierniewski et al. (2018a) studied deeply plowed (Pd) soils of different textures in Poland, France and Israel which were covered by large clods with diameters of up to tens of $\mathrm{cm}$, described by the HSD and $T_{3 \mathrm{D}}$ indices as reaching $30-60 \mathrm{~mm}$ and $1.5-1.6$, respectively. The soils treated by smoothing harrows (Hs) had aggregates with a size below $1 \mathrm{~cm}$, their HSD reached about $8 \mathrm{~mm}$, and their $T_{3 \mathrm{D}}$ values were below 1.1. The overall $\alpha$ level of the soils formed by Pd compared to the same soils, but treated by Hs was about 20-33\% lower. Drops of rain or water droplets created by sprinklers reduced the irregularity of the soil surfaces. The raindrop energy physically disintegrates soil aggregates and rearranges soil particles creating soil crust, a thin layer forms on the soil surface after high-intensity rainfall (BenDor et al. 2003; Eshel et al. 2004; Goldshleger et al. 2001, 2004). After drying, the surface $\alpha$ value clearly increases. De Jong et al. (2011) reported that $\alpha$ of crusted soil surface was from 8 to $40 \%$ higher than of non-crusted soil surfaces. Kondratyev and Fedchenko (1980) reported that the crust, which is formed around soil clods as a result of repetitive wetting and drying, resulted in an increase of 10-15\% in the spectral reflectance of soils. Cierniewski et al. (2015), analyzing the diurnal $\alpha$ variation for bare cultivated soils in Poland and Israel, under clear-sky conditions, found that the soil's roughness not only affected the overall level of $\alpha$, but also the steepness of its rise from $\theta_{\mathrm{s}}$ at local solar noon to about $75^{\circ}$. Soils which are deeply plowed or treated by a planter showed almost no rise in $\alpha$ values at $\theta_{\mathrm{s}}$ lower than $75^{\circ}$, while the same soils smoothed out exhibited a gradual $\alpha$ increase at these angles.

$\alpha$ of the Earth's surfaces or their components, such as bare soils, is used to describe the energy transfer between soil, vegetation, and the atmosphere and to model the environmental biophysical processes associated with this phenomenon on the regional and global scales (Ben-Gai et al. 1998; Schneider and Dickinson 1974). Smoothing rough soils, which had previously been deeply plowed, increases their albedo, which results in a lower amount of shortwave radiation being absorbed by their surface layer. These surfaces also emit less long-wave radiation, leading to a reduction in their temperature, which can affect the climate (Davin et al. 2007). In view of the $\alpha$ variations of bare soils discussed above, as well as the statement of Sellers et al. (1995) about the acceptable error lower than $\pm 2 \%$ of $\alpha$ of the Earth's land surfaces for modeling climate changes on a global scale, the use of their average diurnal $\left(\alpha_{\mathrm{d}}\right)$ values or the averaged values over longer periods of several days, a month, a season, or a year for this modeling seems to be more useful than the use of instantaneous $\alpha$ values (Grant et al. 2000; Cierniewski et al. 2014). So far, the $\alpha_{\mathrm{d}}$ values of bare soils have also been used to estimate the annual dynamic of shortwave radiation reflected from bare soils as a consequence of the smoothing of previously plowed and disk-harrowed fields in Poland (Cierniewski et al. 2017) and reflected from arable lands in Israel (Cierniewski et al. 2018b).

Using the soils with various properties collected in Poland, Israel and France, Cierniewski et al. (2018a) proposed equations that can be used to calculate $\alpha_{\mathrm{d}}$ values of soils with specified roughness, depending on $\theta_{\mathrm{s}}$, using their laboratory reflectance spectra and their roughness indices predicted as a result of shaping their surfaces by specific agricultural tools. The accuracy of the equations expressed by the coefficient of determination and root mean square error was estimated at 0.91 and 0.03 , respectively. Having these equations, and also using laboratory reflectance spectra of bare soils stored in a soil database as well as geostatistical data sets describing the spatial distribution and acreage of bare soils, where major crops are cultivated, the annual dynamics of shortwave radiation reflected from bare arable lands in Europe was estimated (Cierniewski et al. 2018c).

The goal of this study was to use the above-mentioned equations to estimate the highest possible amounts of shortwave radiation that could be reflected throughout the year from bare arable lands on global scale in the most extensive agricultural regions on six of the Earth's continents, where major crops are cultivated. It was assumed that the highest levels of soil radiation would occur during clear-sky conditions when the surfaces that had been conventionally tilled were bare for several days or more after the day of planting and were air-dried in two extreme roughness states: those formed by a plow (Pd) and those formed by a smoothing harrow (Hs).

\section{Materials and methods}

The study areas are arable lands in the largest agricultural regions of the world, where major crops are cultivated according to the Major World Crop Areas and Climate Profile (USDA 1994). For a clear presentation of the annual dynamics of shortwave radiation reflected from bare soils of these arable lands on a global scale, they have been aggregated into six possible large continental super-regions, whose names result from their location on specific continents of the Earth. These are:

- Africa (AF) covering 5 regions: North-western (AFnw), Western (AFwe), Central (AFce), Eastern (AFea), Southern including Madagascar (AFsm);

- Asia (AS) divided into 10 parts: the former republics of the Soviet Union in Central Asia (Kazakhstan, Uzbeki- 
stan, Kyrgyzstan, Turkmenistan, Tajikistan) (AScr), the Middle East and Egypt (ASme), China and Mongolia (AScm), Western India (ASwi), Eastern India (ASei), Southern India (ASsi), Indonesia and Malaysia (ASim), Japan and South Korea (ASjk), the Philippines (ASph) and South-East Asia (ASse);

- Europe (EU) split into 4 parts: the European Union and its associated countries (Switzerland and Norway), plus the countries of the former Yugoslavia outside the European Union, divided into 3 sub-regions: Western (EUwe), Central (EUce) and Southern (EUso), and the Russian Federation with the former republics of the Soviet Union (Belarus, Ukraine, Azerbaijan, Armenia, Georgia) (EUrr);

- North and Central America (NA) including 8 regions: Canada (NAca), the United States (West (NAwe), Midwest (NAmw), Northeast (NAne) and South (NAso)),
Mexico (NAme), Central America (NAce) and the Caribbean (NAca);

- South America (SA) covering 3 regions: Brazil (SAbr), the Andean States (SAas) and the Southern Cone (SAsc);

- Oceania (OC) comprising 3 regions: Australia (East (OCae) and West (OCaw)), New Zealand (OCnz) (Fig. 1).

Geostatistical data sets were used in a multistage procedure to achieve the goal of the study (Fig. 2). In the first stage of the procedure, the areas of major crops present in each region were located, and the periods and amount in which the arable soils were not covered by any vegetation sufficiently to change their spectral characteristics were determined. The data set of the geographic distribution of crops (Monfreda et al. 2008) is a collection of several raster images, each consisting of pixels measuring $5 \times 5$ arc minutes (around 10 by $10 \mathrm{~km}$, depending on latitude), covering
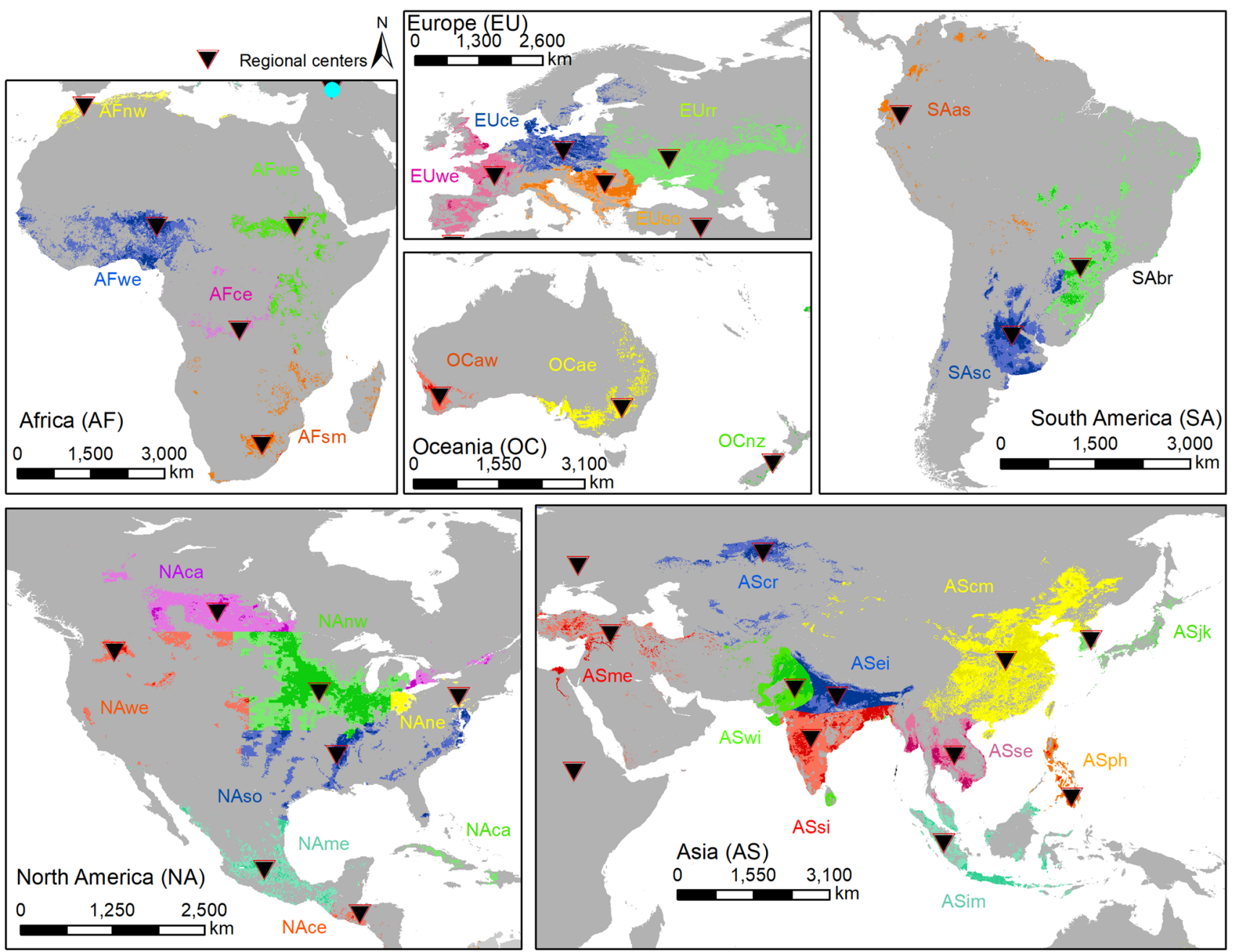

Fig. 1 Division of the world into the agricultural super-regions. Colored abbreviations—names of the regions as in Study Areas and Methods section 


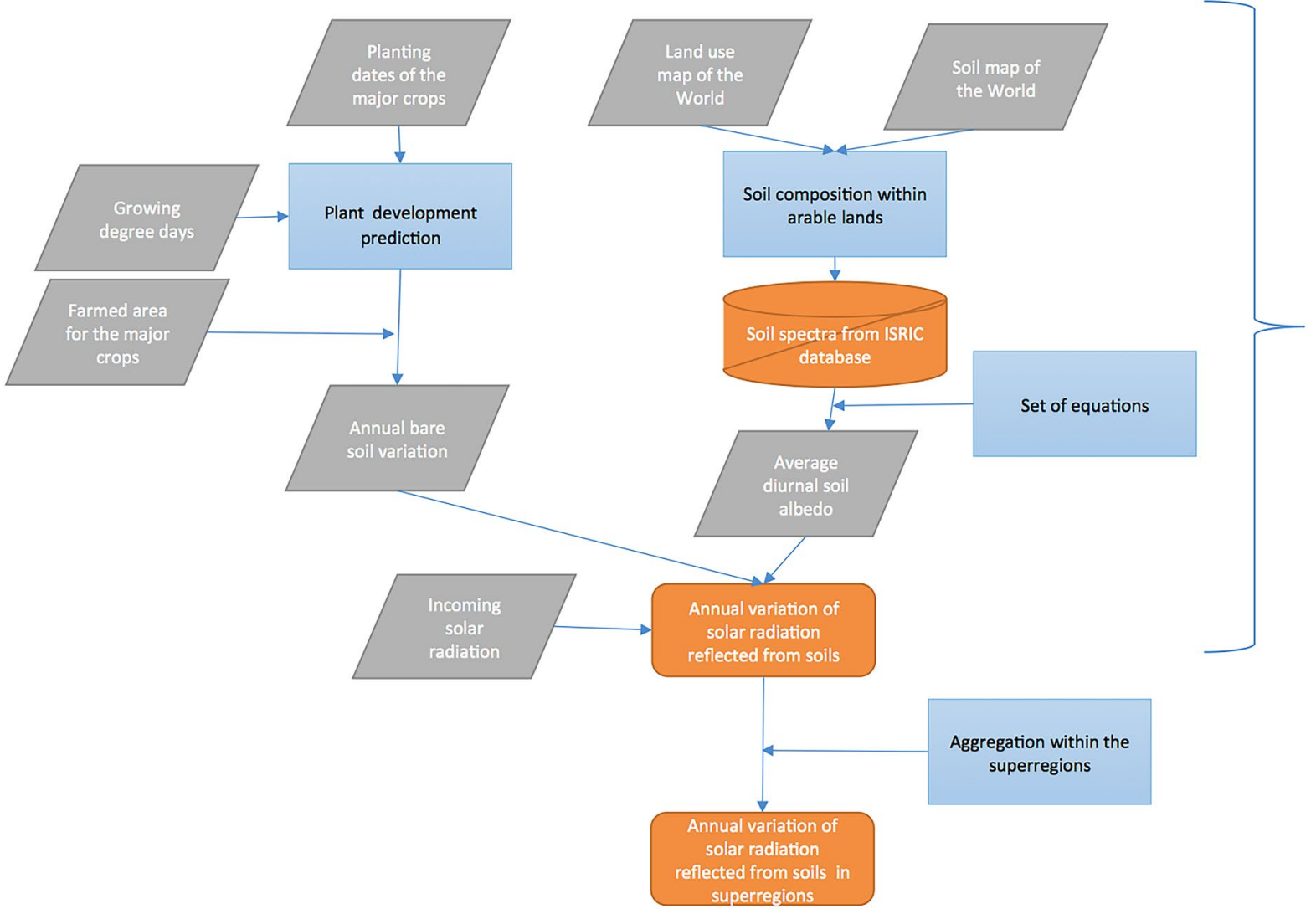

Fig. 2 General flowchart of the procedure

the Earth's land areas (Table 1). For each of the 13 major crops, a separate raster file was provided, and each pixel represented the number of hectares, in the year 2000, that were being utilized for the cultivation of a particular crop within the pixel. Delimiting the maps to each of the regions listed above and totaling the values of hectares from the pixels lying inside them allowed the composition of the crops being cultivated in those regions to be determined. In addition, the central point of agricultural lands for each region was located; this was used to extract the average temperatures and irradiance occurring in each region.

The periods when arable lands were not covered by vegetation (sufficiently to change its spectral characteristics) were found by combining the aforementioned geographic distribution of crops with The Crop Calendar Data Set (Sacks et al. 2010). The crop calendar contains data related to planting days for major crops around the world (also with a resolution of $5 \times 5$ arc minutes). For all of the 33 regions listed above, the number of hectares being used for the cultivation of any given plant was added up separately for each possible planting day of each crop. The result of this operation was a list of the days in the year when each crop is planted, together with the specification of the area it occupies. To find the periods in which the soil remained bare after planting, it was necessary to predict the plant development. Baumgardner et al. (1986) stated that soil starts to demonstrate vegetal
Table 1 Auxiliary data set used in the procedure

\begin{tabular}{ll}
\hline Name & Source \\
\hline $\begin{array}{l}\text { Farming the planet: 2. Geographic distribution of crop areas, yields, physiological } \\
\text { types, and net primary production in the year 2000 }\end{array}$ & Monfreda et al. (2008) \\
Crop planting dates: an analysis of global patterns & Sacks et al. (2010) \\
Global temperature data sets & https://ncar.ucar.edu \\
$\begin{array}{l}\text { Digital Soil Map of the World } \\
\text { Global Land Cover Map }\end{array}$ & FAO/UNESCO (2007) \\
Global Soil Spectral Library & GlobCover (2009) \\
& ISRIC \\
\hline
\end{tabular}


characteristics when crops start to cover more than $15 \%$ of the soil surface. Plant phenological changes were simulated by the amount of Growing Degree Days (GDD) needed to reach the development stage (covering over 15\% of the surface). The GDDs were calculated by adding up the average daily temperatures, which are above the threshold for a given crop, based on averaged data from a 10-year period (1990-2000), obtained from the National Center for Atmospheric Research (https://ncar.ucar.edu). For the major crops analyzed in this paper, the threshold temperature values, as well as the amount of GDDs that should be accumulated, were found in the papers of Miller et al. (2001), Worthington and Hutchinson (2005) and Lee (2011). The distribution of the GDDs through the year was calculated for all the regions, which-along with the planting days-allowed the delimitation of the time windows during which the soil under a particular crop would stay bare. By adding up all of the windows related to all of the major crops and their planting date combinations occurring in a region, the annual cycle of occurrence of bare soils for the region was obtained.

In the second stage, the soil units present in the arable lands within each region were found. The soil units were classified as major soil groupings according to the Digital Soil Map of the World (FAO/UNESCO 2007), which was superimposed on areas classified as croplands, according to a global land cover map (GlobCover 2009). For each region, the composition of areas occupied by the major soil groupings was obtained.

The third stage of the procedure involved finding the averaged soil reflectance spectra for all of the regions. First, the soil units covering at least $5 \%$ of arable area in each region were selected. The soil database of the International Soil Reference and Information Centre (ISRIC) was used to find the spectra of the major soil groupings in the regions (Fig. 3). The ratios of the major soil units were calculated for each region, and the reflectance spectra belonging to those units were extracted. A weighted averaged spectrum for each region was found, with the extracted spectra averaged by weight related to the share of the particular soil unit within arable lands. The spectra relating to the analyzed regions located within the super-regions were then averaged, weighting them according to the area of arable lands.

In the fourth stage, the annual variation of the averaged diurnal soil albedo $\left(\alpha_{\mathrm{d}}\right)$ for each region was calculated using the set of three equations proposed by Cierniewski et al. (2018). The first equation:

$$
\begin{aligned}
a_{45}= & 0.33-0.1099 T_{3 \mathrm{D}}-5795.4 d_{574}-510.2 d_{1087} \\
& +7787.2 d_{1355}+12161 d_{1656}+6932.8 d_{698},
\end{aligned}
$$

describes the overall $\alpha$ level of the soils with given roughness at $\theta_{\mathrm{s}}=45^{\circ}\left(\alpha_{45}\right)$, where $T_{3 \mathrm{D}}$ is roughness index defined

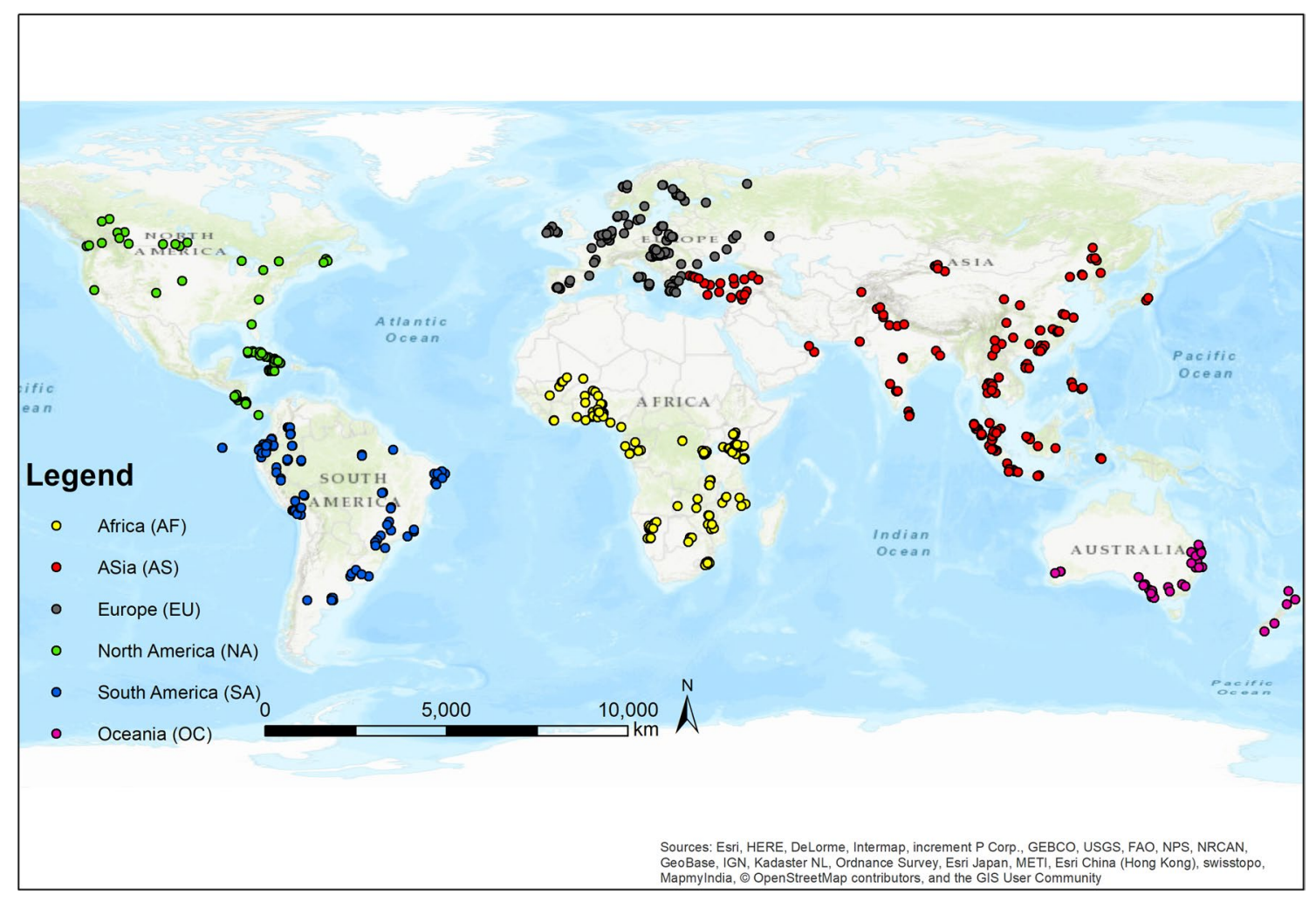

Fig. 3 Location of the soil samples used in the study 
in "Introduction", and $d$ together with its associated number stands for soil reflectance data transformed to its second derivative for a specified wavelength in $\mathrm{nm}$. Those wavelengths were selected from laboratory reflectance spectra (in the range between of 400 and $2500 \mathrm{~nm}$ ) based on 153 soil samples collected in Poland, Israel, and France. The $\alpha$ values of studied soil surfaces $\left(\alpha_{\theta_{\mathrm{s}}}\right)$ under $\theta_{\mathrm{s}}<75^{\circ}$ were calculated using the second equation:

$\alpha_{\theta_{s}}=\alpha_{45}\left[1+s_{\alpha}\left(\theta_{s}-45\right)\right]$,

$s_{\alpha}=6.26 \times 10^{-7}+0.00043(\mathrm{HSD})^{-1.418}$,

where $s_{\alpha}$ is the slope of the $\alpha$ rise relative to $\theta_{\mathrm{s}}$ under $\theta_{\mathrm{s}}<75^{\circ}$, and HSD is another roughness index also defined in "Introduction". Assuming that $\alpha$ of the soil surfaces at $\theta_{\mathrm{s}}=90^{\circ}$ equals one, and having their $\alpha_{\theta_{\mathrm{s}}}$ values calculated for $\theta_{\mathrm{s}}<75^{\circ}$, their half-diurnal $\alpha$ could be fitted for the $\theta_{\mathrm{s}}$ range from $0^{\circ}$ to $90^{\circ}$ using the third equation:

$\alpha_{\theta_{\mathrm{s}}}=\exp \left(\frac{a+c \theta_{\mathrm{s}}}{1+b \theta_{\mathrm{s}}+d\left(\theta_{\mathrm{s}}\right)^{2}}\right)$,

where $a, b, c$, and $d$ are fitting parameters. The half-diurnal $\alpha$ distributions were individually fitted for all of the regions. For the averaged diurnal $\alpha$ analyzed using the above equations, two roughness states of the soil surface were considered, formed by Pd and Hs. The roughness statistics expressed by the previously mentioned indices were as follows: HSD: $25 \mathrm{~mm}$ and $5 \mathrm{~mm}$ and $T_{3 \mathrm{D}}: 1.5$ and 1.05 for Pd and Hs, respectively (Cierniewski et al. 2018).

In the fifth stage, the $\alpha_{\theta_{s}}$ distributions of the soils representing the regions in the full $\theta_{\mathrm{s}}$ range were transformed to the function of solar local time (SLT) for every tenth day of the year for the centers of the regions. Those simulated $\alpha_{\mathrm{d}}$ variations were then averaged, and the annual $\alpha_{\mathrm{d}}$ variation was obtained by interpolating values for the missing days.

In the sixth stage, the annual variance of the reflected solar energy for soils formed by Pd and Hs was calculated. First, the annual variation of incoming shortwave radiation $\left(\mathrm{Ri}_{\mathrm{d}}\right)$ in clear-sky conditions for each region had to be approximated. Once again, the amount for each region was based on its center. The theoretical amount for a unit of area was calculated using equations proposed by Allen et al. (1998). Multiplying $\mathrm{Ri}_{\mathrm{d}}$ by $\alpha_{\mathrm{d}}$ and the area of the bare soils on that day resulted in the total amount of reflected shortwave radiation from a region $\left(\mathrm{Rr}_{\mathrm{d}}\right)$. Performing that process for every day of the year gave the annual distribution of reflected solar radiation, obtained for soils formed by both $\mathrm{Pd}$ and Hs. The difference in reflected radiation due to increased albedo resulting from the smoothing of previously plowed soil surfaces was also calculated. For ease of presentation, the $\mathrm{Rr}_{\mathrm{d}}$ values were added together for the regions belonging to the same super-region.

\section{Results}

Thirteen cultivated plants are distinguished as the major crops in these analyzed super-regions (Table 2). All the crops grown in AF, listed in this table, occupying the total area of nearly $903,000 \mathrm{~km}^{2}$. Maize, sorghum, millet, and cassava occupy over $73 \%$ of this area. Similarly, a full list of these crops is present in AS. In total, they cover an area over 2.5 times larger: 2,389,000 $\mathrm{km}^{2}$. Wheat dominates across almost $40 \%$ of this area and, together with maize and cotton, covers over $65 \%$ of arable land of the largest continental super-region. The list of major crops in the EU area contains one less item, covering an area of $1,386,000 \mathrm{~km}^{2}$. The crops covering the largest area-wheat (almost $47 \%$ ), together with barley and maize-occupy almost $78 \%$ of the area. The list of major crops in NA and SA includes 13 crops. Almost $74 \%$ of the total area of NA, exceeding $982,000 \mathrm{~km}^{2}$, is covered by either maize (over $40 \%$ ) or wheat (almost $34 \%$ ). The largest share in the area of arable land in SA, with over $566,000 \mathrm{~km}^{2}$, belongs to soybeans (almost $43 \%$ ) and maize (29\%). Only $15 \%$ of this area is covered by wheat. The list of major crops in the smallest super-region, OC, includes only 6 crops. Their cultivation occupies $180,000 \mathrm{~km}^{2}$. The largest part, over $77 \%$ of this area, is covered by wheat.

The areas of major soil groupings and their share in each of the super-regions are shown in Table 3. Luvisols and Arenosols represent more than 50\% of the total AF area. With the addition of Vertisols, Regosols, Lithosols, and Cambisols, this number increases to above $76 \%$. The AS area is more divers in terms of soils. Five major soil groupings-Lithosols, Cambisols, Gleysols, Luvisols, and Histosols - occupy almost 59\% of its total area. Two major soil groupings, Charnozems and Cambisols, cover almost $50 \%$ of the EU area, and with the addition of Luvisols and Histosols, this combined share increases to a cover of over $74 \%$. Two soil units other than those previously mentionedKastanozems and Luvisols - cover more than 55\% of the NA area. With the addition of Phaeozems and Yermosols, they account for $82 \%$ of this area. In SA, two soil groupingsFerralsols and Phaeozems - cover almost 50\% of the area. Three major groupings-Luvisols, Arenosols, and Kastanozems - increase its total area to almost $77 \%$. Two groupings-this time, Luvisols and Planosols-cover over 50\% of the OC area. Solonetz and Vertisols expand its total area to over $81 \%$.

The average reflectance spectra representing the major soil groupings within $\mathrm{AF}, \mathrm{AS}, \mathrm{EU}$, and NA are similar to each other, especially for wavelengths above the near-infrared (Fig. 4). Average spectra relating to the soil units in OC 


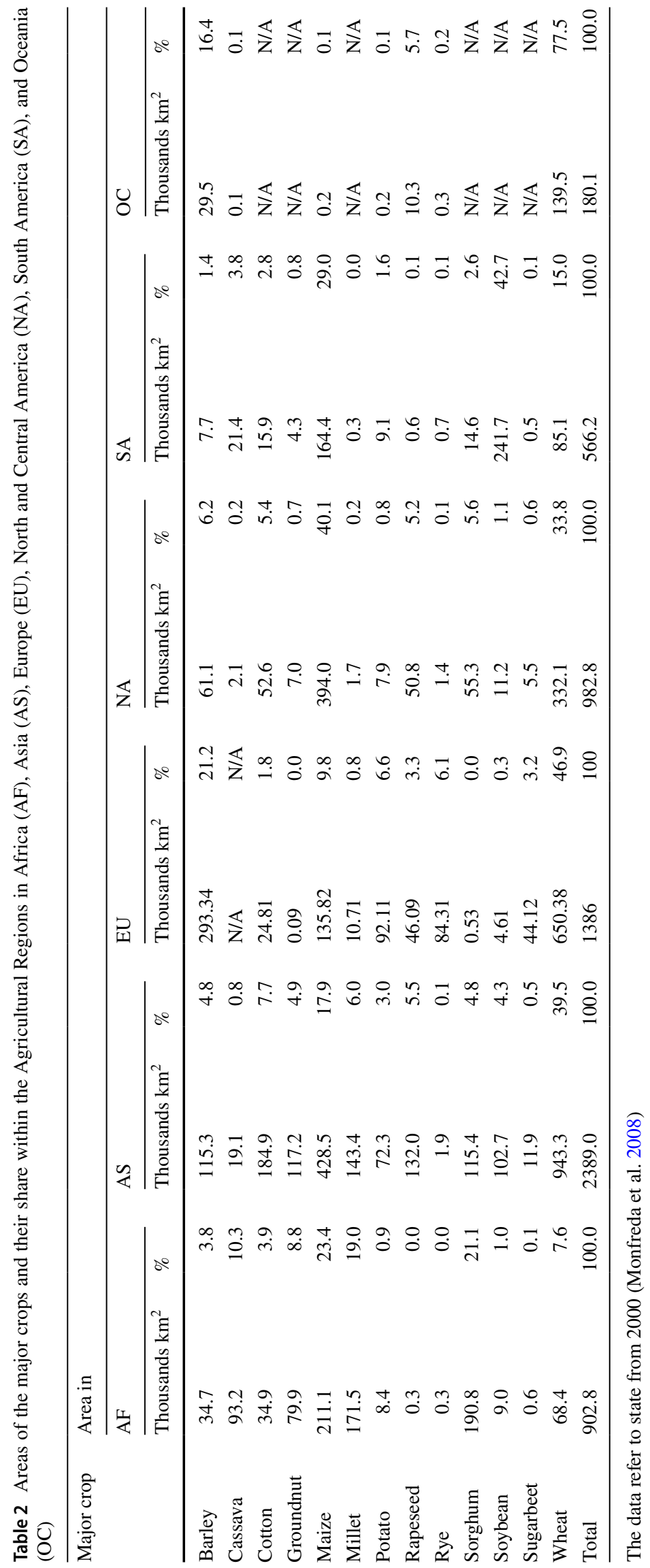




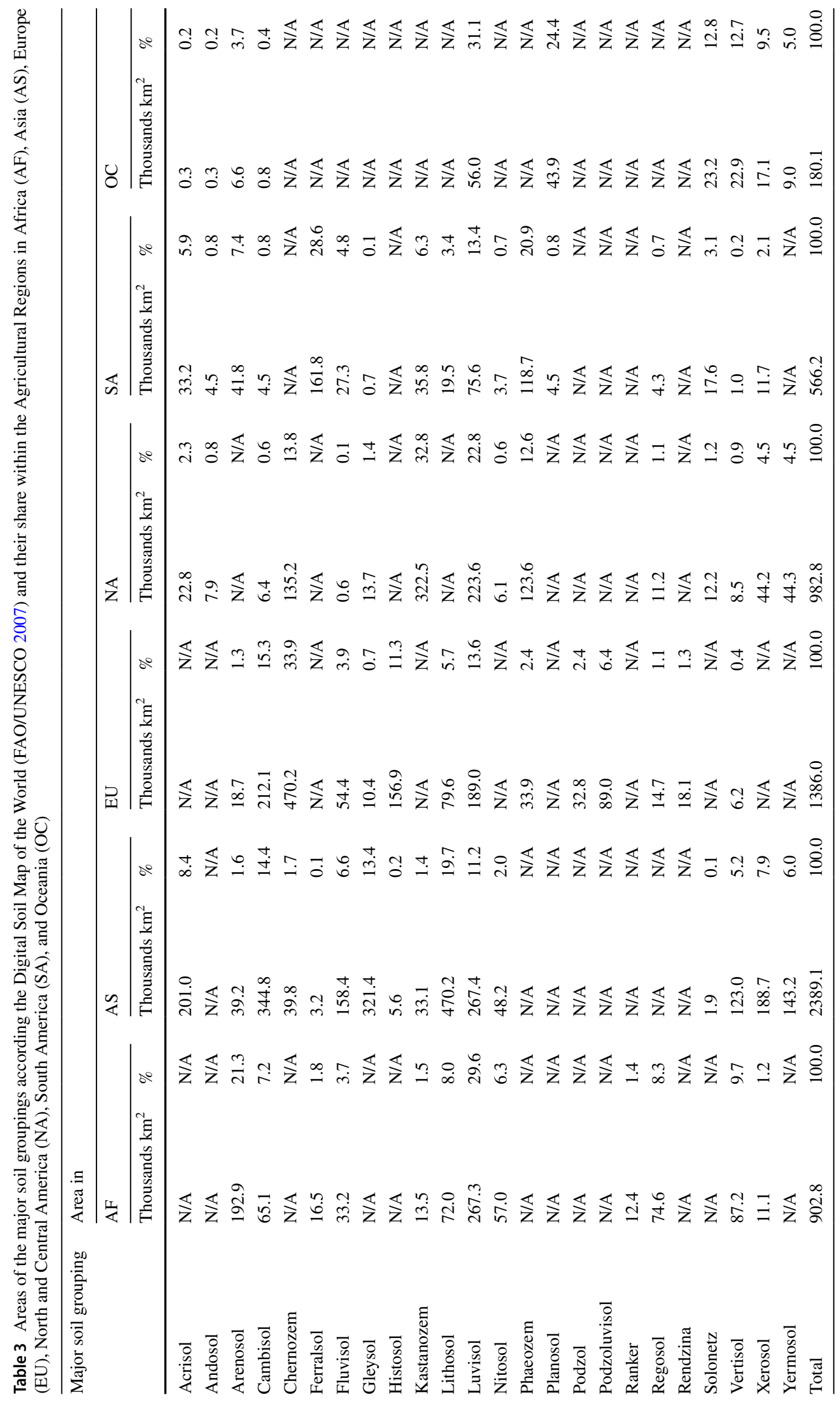




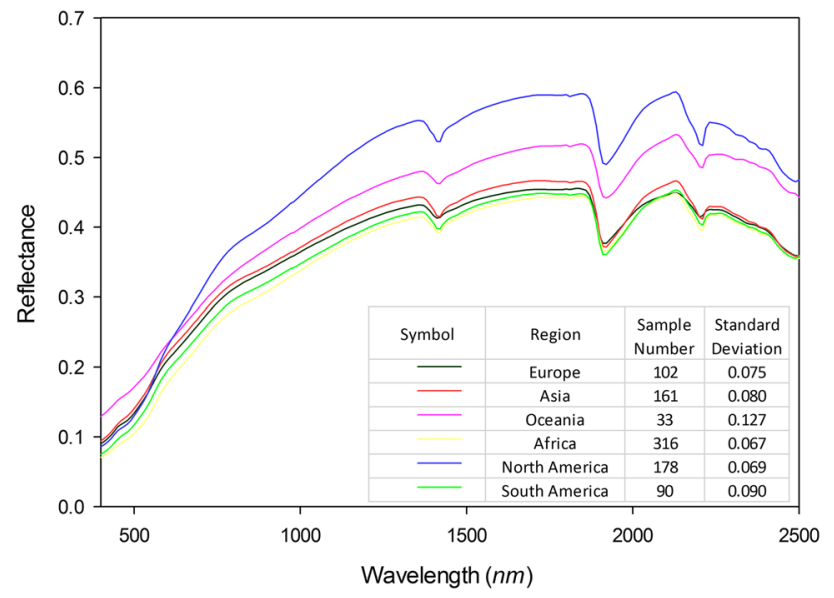

Fig. 4 Spectra of averaged soils within the analyzed super-regions, with the number of averaged samples and the standard deviation of the averaged reflectance value of the spectra representing the soils of 6 continents

and SA show about $20 \%$ and $35 \%$ higher reflectance than the spectra mentioned above.

The annual distributions of the bare soil areas $\left(A_{\mathrm{d}}\right)$ in each continental super-region, presented in Fig. 5, are the result of the aggregation of the bare soil units related to the individual major crops cultivated in all agricultural regions analyzed within it. Due to the large extent of the majority of the six analyzed super-regions in terms of latitude, the $A_{\mathrm{d}}$ values prepared for planting the major crops there, listed in Table 2, were found over wide periods.

The AF super-region is located in both hemispheres of the Earth. Due to the dominant crop areas in agricultural regions located in the Northern Hemisphere, the largest $A_{\mathrm{d}}$ values in AF result from the cultivation of soils there. These $A_{\mathrm{d}}$ values occur in spring and summer, between $31 \mathrm{March}$, and 20 April and between 30 May, and 23 August, reaching in these periods around 10 April and 4 July about $150,000 \mathrm{~km}^{2}$ and $350,000 \mathrm{~km}^{2}$, respectively. The $A_{\mathrm{d}}$ values in south of $\mathrm{AF}$ in the same seasons, but between 11 November and 5 January the following year do not excess $70,000 \mathrm{~km}^{2} /$ day. The large $A_{\mathrm{d}}$ within AS occurring from 14 February to 9 June are mainly the results of their cultivation in the agricultural regions of China, as well as the Middle East and Egypt. Two large $A_{\mathrm{d}}$ peaks, reaching almost $600,00 \mathrm{~km}^{2}$ and $700,000 \mathrm{~km}^{2}$ around 5 April and 25 May, respectively, are results of the soil cultivation happening in Western India and the former republics of the Soviet Union in Central Asia. In the summer, up to 18 August, there is a third large $A_{\mathrm{d}}$ with its peak around 19 July, resulting from the planting of crops in the three regions of India (Southern, Western, and Eastern). In autumn and winter, from 11 November to 15 January of the subsequent year, a smaller $A_{\mathrm{d}}$ with its peak around 16 December was found, resulting from the cultivation of soils in the above-mentioned regions of China, India, and the Middle East.

The large $A_{\mathrm{d}}$ within the EU area occurs between approximately 9 February and 9 June. It is possible to distinguish four broad maxima within this period. The first, reaching around 6 March almost $130,000 \mathrm{~km}^{2}$, corresponds to its southern agricultural region (EUso). The second maximum, reaching 31 March about $180,000 \mathrm{~km}^{2}$, refers to the EUso and western (EUwe) regions of EU, as well as the region including the Russian Federation and the former European republics of the Soviet Union (EUrr). The third and fourth maxima, which occur around 10 May and 25 May, reaching almost $300,000 \mathrm{~km}^{2}$ and about $450,000 \mathrm{~km}^{2}$, respectively, refer mainly to the EUrr and the Central EU region (EUce). In addition to the spring peaks of $A_{\mathrm{d}}$ in EU, there are also peaks between the 230th DOY (18 August) and the 290th DOY (17 October) with summer-autumn maxima below $200,000 \mathrm{~km}^{2}$, which are mainly related to the regions of EUrr and EUce.

$A_{\mathrm{d}}$ within the NA area was established between 20 April and 9 July with its peak around 20 May reaching almost $300,000 \mathrm{~km}^{2}$. Soil from the Midwest regions of the United States and soils in Canada have the greatest impact on their total area. In the autumn, from around 7 October to 26 November, $A_{\mathrm{d}}$ reached about $200,000 \mathrm{~km}^{2}$. The soils in Canada have the greatest impact on this area during this period.

The largest areas of arable land in the SA are found in Brazil in the Southern Hemisphere, and the largest $A_{\mathrm{d}}$ occurs there in spring. From 2 October to 21 November, these areas total an average of $70,000 \mathrm{~km}^{2}$, and then up to 16 December they rise sharply, reaching their peak, at almost $500,000 \mathrm{~km}^{2}$ around 6 December. Mostly, the soils of Brazil determine the areas during this period. In summer, around 25 January, they reach $100,000 \mathrm{~km}^{2}$, mainly due to the soils in the countries of the Southern Cone.

The largest total $A_{\mathrm{d}}$ values in the OC belong to the Australian regions and were found in autumn. Between 15 and 30 May, the area reaches about $12,000 \mathrm{~km}^{2}$. By around 19 June, it doubles to $25,000 \mathrm{~km}^{2}$. At the turn of autumn and winter, around $14 \mathrm{July}$, it is about $5000 \mathrm{~km}^{2}$, and by 3 August, it is about $2000 \mathrm{~km}^{2}$. From spring until mid-summer, from 16 November to 15 January, the area of bare soils is on average $5000 \mathrm{~km}^{2}$.

The diurnal amount of shortwave radiation reaching specific places on the Earth in clear-sky conditions $\left(\mathrm{Ri}_{\mathrm{d}}\right)$ depends on the day of the year and the latitude at which it is located. Due to the large extents of the analyzed six continental agricultural super-regions in relation with latitude, the annual variation of maximum $\mathrm{Ri}_{\mathrm{d}}$ is illustrated based on the examples of the centers of two selected agricultural regions located in the Northern Hemisphere, in Africa's AFwe near the equator $\left(11.22^{\circ} \mathrm{N}, 8.50^{\circ} \mathrm{E}\right)$ and at medium-average 

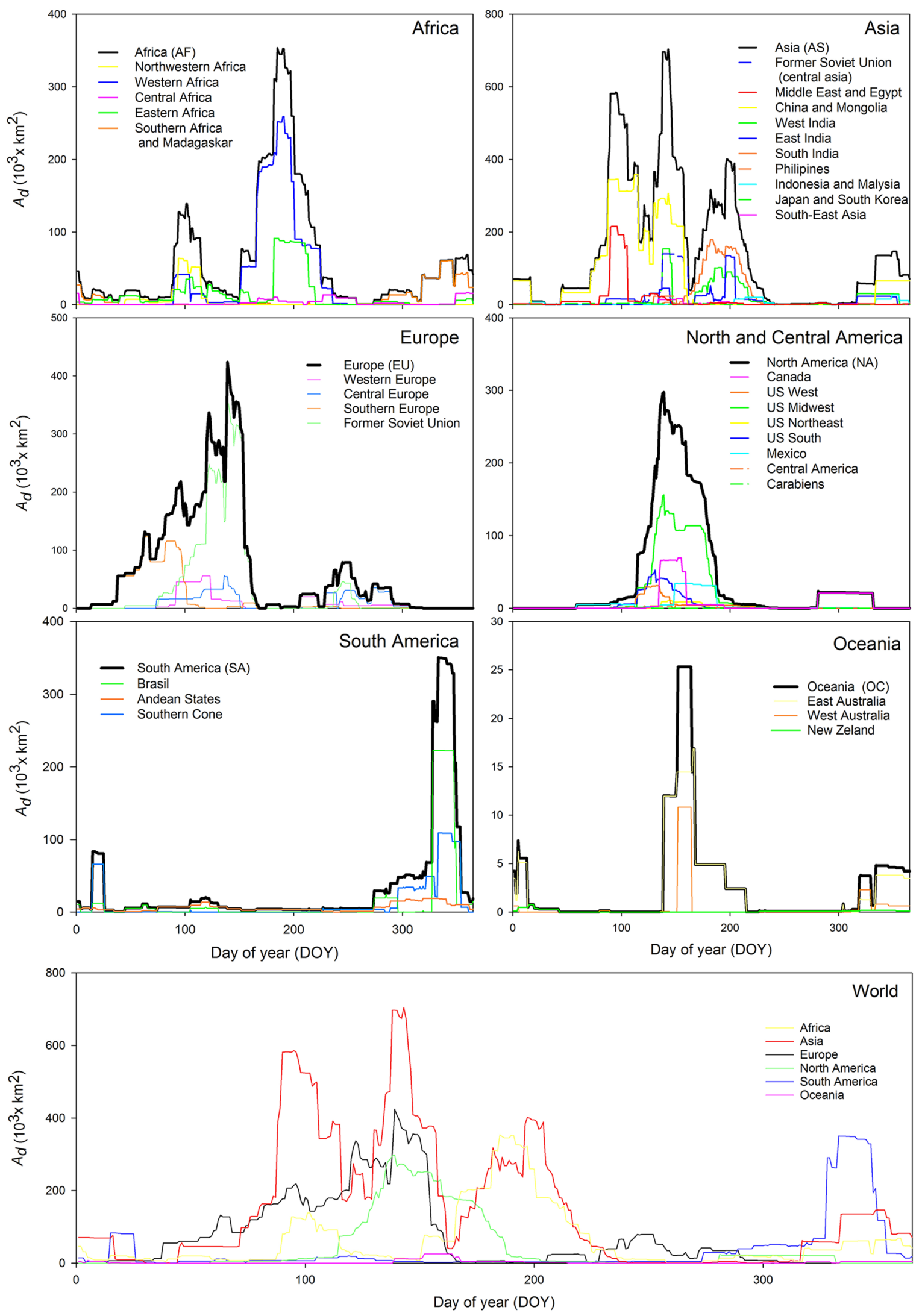

Fig. 5 Annual bare soil $\left(A_{\mathrm{d}}\right)$ distribution for all regions, aggregated by the super-regions 
latitudes in Europe's EUrr $\left(49.96^{\circ} \mathrm{N}, 34.67^{\circ} \mathrm{E}\right)$, as well as the center of one region in the Southern Hemisphere in SAbr $\left(23.75^{\circ} \mathrm{S}, 52.00^{\circ} \mathrm{W}\right)$ (Fig. 6a). As the examples show, the higher the latitude, the greater the annual variation of the $\mathrm{Ri}_{\mathrm{d}}$. On the shortest day of the year, at the beginning of the astronomical winter, $\mathrm{Ri}_{\mathrm{d}}$ reaches about $6 \mathrm{TJ} / \mathrm{km}^{2}$ / day, $17 \mathrm{TJ} / \mathrm{km}^{2} /$ day, and $23 \mathrm{TJ} / \mathrm{km}^{2} /$ day in EUrr, SAbr, and AFwe, respectively, and at the longest day, at the beginning
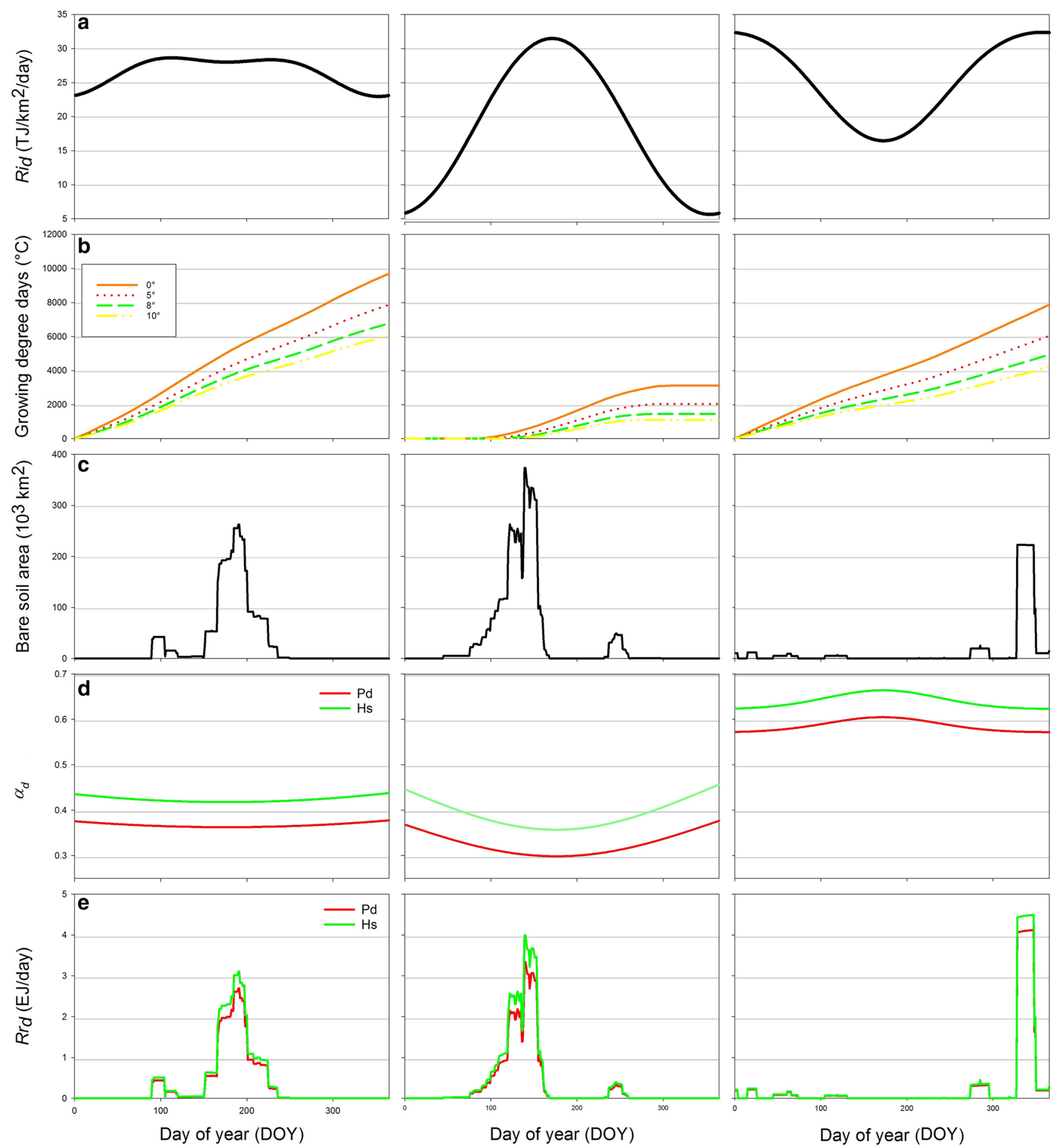

Fig. 6 Annual variations for Western Africa, Former Soviet Union and Brasil in: a diurnal amount of incoming shortwave radiation $\left(\mathrm{Ri}_{\mathrm{d}}\right)$, b accumulation of growing degree days (GDD) for four base temperatures, $\mathbf{c}$ extents of bare soils in a given day of year, $\mathbf{d}$ aver- age diurnal albedo $\left(\alpha_{\mathrm{d}}\right)$ of the averaged bare soils formed by a plough (Pd) and a smoothing harrow (Hs) and e total amount of reflected shortwave radiation $\left(\mathrm{Rr}_{\mathrm{d}}\right)$ for soils formed by $\mathrm{Pd}$ and $\mathrm{Hs}$ 
of the astronomical summer, about $32 \mathrm{TJ} / \mathrm{km}^{2} /$ day, $33 \mathrm{TJ} /$ $\mathrm{km}^{2} /$ day, and $28 \mathrm{TJ} / \mathrm{km}^{2} /$ day, respectively. This annual variation of $\mathrm{Ri}_{\mathrm{d}}$ also affects the annual dynamics of $\alpha_{\mathrm{d}}$ of the bare soils located there. The accumulation of the GDDs for the regions, calculated for base temperature values of $0,5,8$, and $10{ }^{\circ} \mathrm{C}$, is used to determine the periods of bare soil, as presented in Fig. $6 \mathrm{~b} . A_{\mathrm{d}}$ of the presented regions, obtained by combining the planting dates and the GDDs, is shown in Fig. 6c. Assuming that in the centers of the analyzed regions-EUrr, AFwe, and SAbr, there are soils characterized by the reflectance spectra which are the effect of averaging all soil spectra within the region (in proportion to the area of soils occurring there), the annual variation of $\alpha_{\mathrm{d}}$ of these bare soils in these regions can be characterized, as shown in Fig. 6d. It was found that, on average throughout the year, $\alpha_{\mathrm{d}}$ of the averaged soils within EUrr, AFwe, and SAbr smoothed by $\mathrm{Hs}$ is higher by about $20 \%, 15 \%$, and $10 \%$, respectively, compared to the same soils previously plowed using Pd. In the spring, when these averaged soils are bare in both hemispheres, the highest $\alpha_{\mathrm{d}}$ values, between 0.61 and 0.67 , refer to the soils in SAbr with their higher overall reflectance level (Fig. 4). $\alpha_{\mathrm{d}}$ of the averaged soils in this period reaches values between 0.37 and 0.42 within AFwe, and 0.30 and 0.36 in EUrr. These $\alpha_{\mathrm{d}}$ values of the analyzed soils also allow an approximation to be made of how much more shortwave radiation $\left(\mathrm{Rr}_{\mathrm{d}}\right)$ can be reflected from them as a result of smoothing by Hs only. It was found that these increases in the amount of $\mathrm{Rr}_{\mathrm{d}}$ with regard to incident radiation could reach about $1.8 \%, 1.3 \%$, and $1.8 \%$ within EUrr, AFwe, and SAbr, respectively. Multiplying the above $\alpha_{\mathrm{d}}$ values by the $A_{\mathrm{d}}$ peaks of these soils formed by $\mathrm{Pd}$ and $\mathrm{Hs}$, the target maxima amounts of $\mathrm{Rr}_{\mathrm{d}}$ radiation that could be reflected from them in their air-dried state in clear-sky conditions were evaluated for the centers of the regions (Fig. 6e). These $\mathrm{Rr}_{\mathrm{d}}$ amounts for the EUrr, AFwe, and SAbr regions, with their $A_{\mathrm{d}}$ maxima reaching about $370,000 \mathrm{~km}^{2}, 270,000 \mathrm{~km}^{2}$, and $220,000 \mathrm{~km}^{2}$, can reach values in the range 3.7-4 EJ/day, 2.7-3.2 EJ/day, and 4.2-4.5 EJ/day, respectively.

Data describing the $\mathrm{Rr}_{\mathrm{d}}$ variations within the superregions resulting primarily from the maximum $A_{\mathrm{d}}$ values of soil surfaces formed by $\mathrm{Pd}$ and $\mathrm{Hs}$ are presented in this order below (Fig. 7). The peaks of $\mathrm{Rr}_{\mathrm{d}}$ in the AF area, occurring around 10 April in spring and 9 July in summer, were evaluated at about $1.2 \mathrm{EJ} /$ day and $1.5 \mathrm{EJ} /$ day, and $3.5 \mathrm{EJ} /$ day and 4 $\mathrm{EJ} /$ day, respectively. The $\mathrm{Rr}_{\mathrm{d}}$ maxima in the spring and summer in the southern AF region, occurring from 11 November to 5 January of the following year, were estimated at about $0.7 \mathrm{EJ} /$ day and $0.8 \mathrm{EJ} /$ day, respectively. The largest peaks of $\mathrm{Rr}_{\mathrm{d}}$ within AS appearing in spring around 10 April and 25 May were assessed at about $6 \mathrm{EJ} /$ day and $7 \mathrm{EJ} /$ day, and 8.5 $\mathrm{EJ} /$ day and $10 \mathrm{EJ} /$ day, respectively. The third summer $\mathrm{Rr}_{\mathrm{d}}$ peak, occurring around 19 July, was predicted at about 4
$\mathrm{EJ} /$ day and $4.5 \mathrm{EJ} /$ day for $\mathrm{Pd}$ and $\mathrm{Hs}$, respectively. The four peaks of the $\mathrm{Rr}_{\mathrm{d}}$ developing in the EU area in the winter and spring can reflect the following amounts of $\mathrm{Rr}_{\mathrm{d}}$ : (1) about 0.9 $\mathrm{EJ} /$ day and $1.1 \mathrm{EJ} /$ day; (2) $1.8 \mathrm{EJ} /$ day and $2 \mathrm{EJ} /$ day; (3) $3 \mathrm{EJ} /$ day and $3.5 \mathrm{EJ} /$ day; and (4) almost $5 \mathrm{EJ} /$ day and $5.8 \mathrm{EJ} /$ day. It was assessed that the spring $\mathrm{Rr}_{\mathrm{d}}$ peak in NA can reflect about $7 \mathrm{EJ} /$ day and almost $8.5 \mathrm{EJ} /$ day, while the autumn peak can reflect only $0.25 \mathrm{EJ} /$ day and $0.3 \mathrm{EJ} /$ day. The spring $\mathrm{Rr}_{\mathrm{d}}$ peak in SA was estimated at about 5.5 EJ/day and 6.3 EJ/ day, while for the summer peak, it was estimated at about $1 \mathrm{EJ} /$ day and $1.2 \mathrm{EJ} /$ day. It is predicted that the autumn $\mathrm{Rr}_{\mathrm{d}}$ peak in OC, occurring around 4 June, can reach $0.15 \mathrm{EJ} /$ day and $0.25 \mathrm{EJ} /$ day, while during the summer, around the 10th DOY, it can reach $0.03 \mathrm{EJ} /$ day and $0.05 \mathrm{EJ} /$ day.

The annual variation of shortwave radiation from bare soil, concerning arable land used for the cultivation of major crops (typical for a specific agricultural region), was estimated on the scale of the entire globe, adding up the values of $\mathrm{Rr}_{\mathrm{d}}$ obtained for the six analyzed super-regions, day by day (Fig. 8). In this way, it was established that the largest amounts of $\mathrm{Rr}_{\mathrm{d}}$ occur between 31 March and 19 July with their peak around 15 May reaching about $22 \mathrm{EJ} /$ day and almost $25 \mathrm{EJ} /$ day for soils formed by $\mathrm{Pd}$ and $\mathrm{Hs}$, respectively. Therefore, simply smoothing previously plowed soils in this peak period could increase their $\mathrm{Rr}_{\mathrm{d}}$ by up to $3 \mathrm{EJ} / \mathrm{day}$. Significantly lower amounts of $\mathrm{Rr}_{\mathrm{d}}$, in the range 8-10 EJ/day, 8-9 EJ/day, and 7-8 EJ/day, can be expected around 7 April, 4 July, and 6 December, respectively. Smoothing these soils, in comparison with the same soils being plowed, increases their $\mathrm{Rr}_{\mathrm{d}}$ by about $1-1.5 \mathrm{EJ} /$ day during these dates.

\section{Discussion}

The first approximations of a quantitative estimation of shortwave radiation reflected from bare arable lands illuminated at clear-sky conditions, concerning Poland (Cierniewski et al. 2017) and Israel (Cierniewski et al. 2018b), based on extracting their changing areas during the year from Landsat 8 images. It was found that these areas reach two maxima in spring and late summer in Poland and one maximum in summer until early autumn in Israel. Maxima of shortwave radiation reflected from air-dried bare arable lands in Poland were assessed at about 200 and 295 $\mathrm{PJ} /$ day for soils in Poland formed by Pd and Hs, respectively, using the content of soil organic carbon carbonates stored in the Polish soil databases. The values for soils in Israel, calculated from their reflectance spectra stored in the Israeli Soil Library, were about 13-14 times lower than in Poland, mainly because of the 35 times smaller area of arable lands in Israel, but 1.8 times higher shortwave radiation reflected from $1 \mathrm{~km}^{2}$ of the soils in Israel when maximum radiation is incident on them. The dynamics of shortwave radiation 

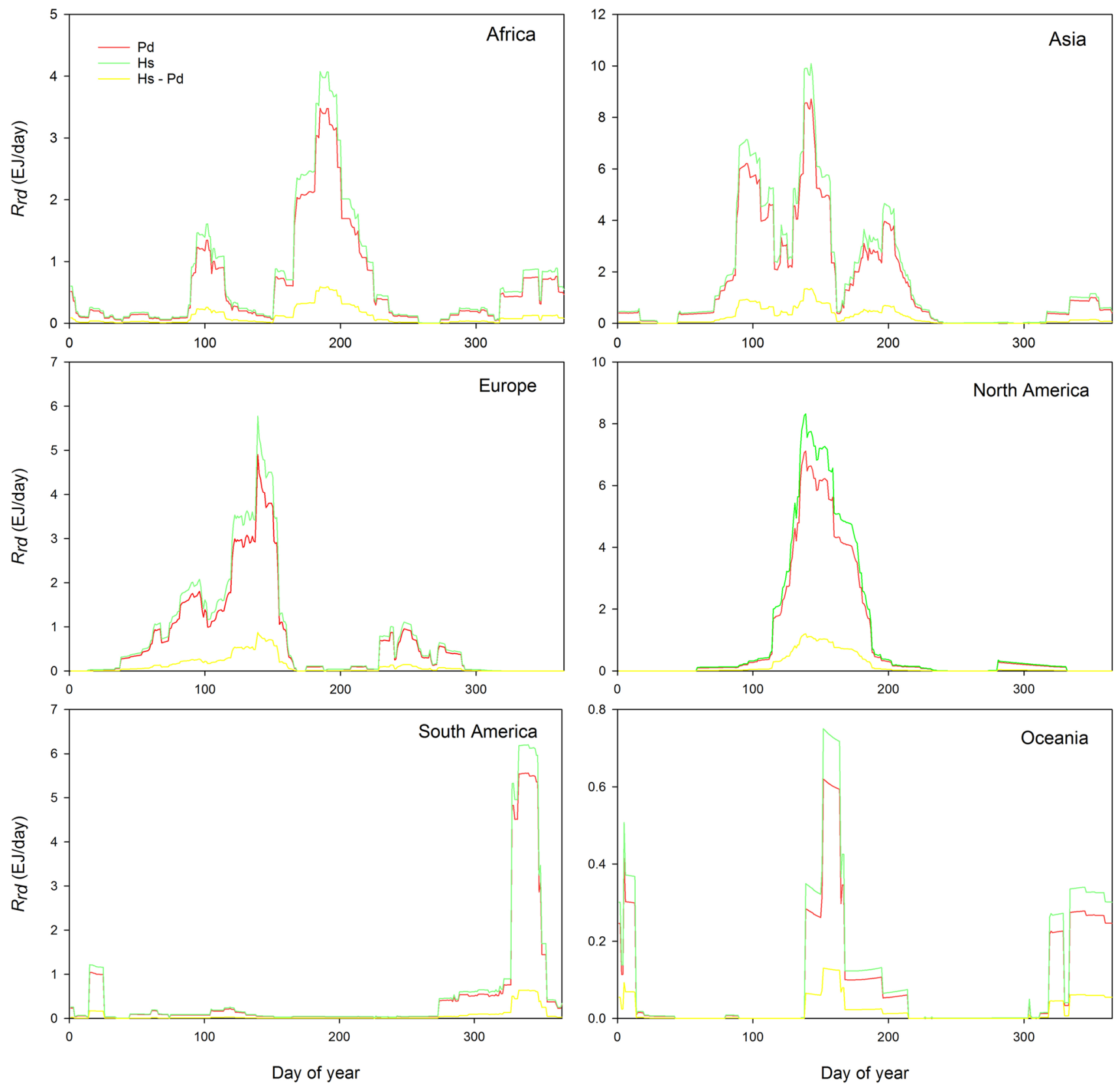

Fig. 7 Reflected shortwave radiation $\left(\mathrm{Rr}_{\mathrm{d}}\right)$ from the surfaces of the super-regions formed by a plow (Pd) and a smoothing harrow (Hs)

reflected from bare arable lands in Europe (Cierniewski et al. 2018c) was estimated using vectorised and rasterized geostatistical data sets (using the same procedure as in this study) to determine the variation of their areas in a year, satellite data from the Spinning Enhanced Visible and Infrared Imager instrument (König et al. 2001), as well as thousands of soil reflectance spectra stored in the European Land Use and Cover Area frame Survey soil database to calculate the radiation reflected from them in changing cloud conditions during the year.
The estimation of the amount of shortwave radiation reflected from arable lands on a global scale, proposed in this study, takes into account the diversity of their spectral reflectance resulting from the spatial variation of soil cover, assuming that they are in two extreme roughness states formed by Pd and Hs and they are air-dried and illuminated under clean skies. The results of research carried out in Poland, Israel, and France on 153 plots treated by various agricultural tools (Cierniewski et al. 2018a) were used here. These plots were located on soils belonging to the 9 major soil groupings occupying 54\% of the total area 


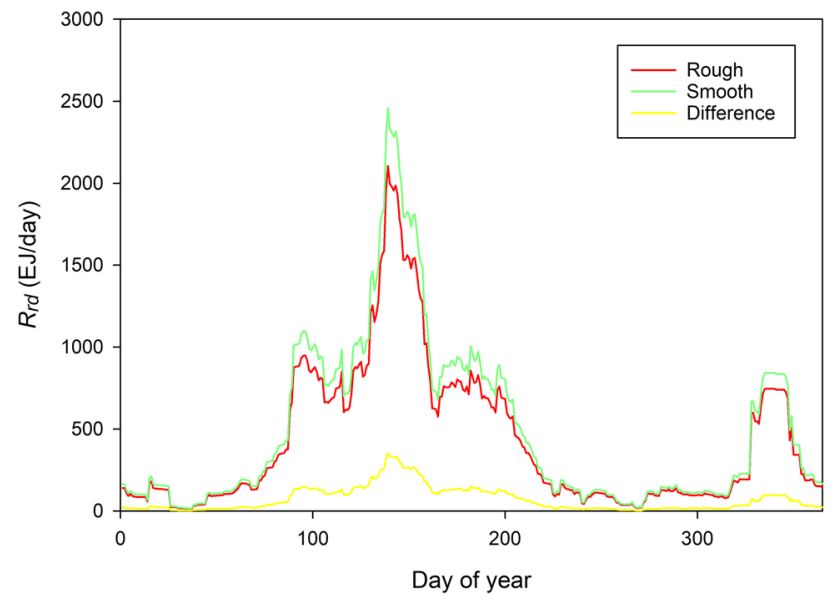

Fig. 8 Global amount of reflected shortwave radiation $\left(\mathrm{Rr}_{\mathrm{d}}\right)$ from all of the analyzed regions

of arable lands in the world classified into 24 soil major grouping (listed in Table 3). The roughness of the arable land in the world was characterized using the mean values of the HSD and $T_{3 \mathrm{D}}$ indices (mentioned in "Materials and methods") obtained from 49 to 58 plots formed by Pd and $\mathrm{Hs}$, respectively. It was assumed that these tools everywhere produce similar effects.

The estimation does not include all the arable lands without crops, because it refers only to the major crops in the analyzed agricultural regions. It has been simplified to conditions, where the reflectance of bare soils is the highest, barring the presence of soil crusts. It uses data, which is relatively easy to access. The time range of the various data sets used spans 13 years, with the geographic distribution of crops from the oldest, in the year 2000, to the newest - an area under conservative tillage-from 2013. However, it was assumed that agriculture, especially in the major regions, is relatively unchanging over time. The authors of this assessment realize that in future approximations, the results will be more precise when it is possible to use data describing the real annual variation of the soil arable areas across whole continents and their irradiation in the clear-sky and in different degrees of cloudiness, as well as obtaining knowledge on the actual state of the soil surfaces.

Not all areas of arable lands on a global scale presented here, established for the major crops using the geostatistical data sets, relate to their cultivation under conventional tillage-the situation when soils prepared for planting crops are bare for several days. In some parts of the areas, the practices of agricultural conservation (including zero tillage) are applied, minimizing the mechanical disturbance of the soil. Consequently, when crops are planted, residues of the previous crops cover the soils in varying degrees. To obtain information on how much the soil areas obtained, using geostatistical data sets should be reduced to characterize
Table 4 Maxima diurnal amount of shortwave radiation reflected from arable lands formed by a plow (Pd) and smoothing harrow (Hs) within Asia (AS), Europe (EU), North America (NA), and South America (SA)

bare soils under conventional tillage, and statistical data obtained from AQUASTAT published by the FAO (http:// www.fao.org/nr/aquastat/) were used. The data refer to 54 countries that reported what proportion of their arable lands were subject to agricultural conservation practices in 2013-2017. The arable lands within these countries represent $73 \%\left(10,358,000 \mathrm{~km}^{2}\right)$ of the total arable land area in the world $\left(14,259,000 \mathrm{~km}^{2}\right)$ in 2015 . In the case of arable land, the areas established for the major crops in the European Union have been reduced in a similar way as in the six continental super-regions, although the data obtained from Eurostat for this area were directly distinguished as referring to "conventional tillage" (Cierniewski et al. 2018c).

\section{Conclusions}

The procedure used in this research project allowed the quantification of the annual dynamics of shortwave radiation reflected from arable soils at two extreme states of roughness resulting from the use of a plow (Pd) and a smoothing harrow (Hs), before the planting of major crops. It concerns the largest agricultural regions of the world-when the soils are not covered by crops and plant residues to an extent that can significantly change the bare soil's reflectance features. The preliminary results refer here to limited and, therefore, simplified conditions when the analyzed soil surfaces are air-dried and reach their highest reflectance during clear-sky conditions.

It was found that the highest peak of shortwave radiation $\mathrm{Rr}_{\mathrm{d}}$ reflected from the soils formed by $\mathrm{Pd}$ and $\mathrm{Hs}$ in Africa occur in summer, reaching there about $3.5 \mathrm{EJ} /$ day and $4 \mathrm{EJ} /$ day, respectively. In Asia (AS), Europe (EU), North America (NA), and South America (SA), the highest $\mathrm{Rr}_{\mathrm{d}}$ peaks appear in spring, reaching there the following values for lands shaped by Pd and Hs (Table 4). In Oceania, this highest $\mathrm{Rr}_{\mathrm{d}}$ peak, appearing there in autumn, was estimated for such shaped soil surfaces at $0.15 \mathrm{EJ} /$ day and $0.25 \mathrm{EJ} /$ day.

Adding together all the $\mathrm{Rr}_{\mathrm{d}}$ values predicted for each of the continental super-regions, day by day, it was found that the highest $\mathrm{Rr}_{\mathrm{d}}$ value, occurring around 20 May, reaches 22 $\mathrm{EJ} /$ day for soils treated by Pd, and when they are smoothed by $\mathrm{Hs}$, their $\mathrm{Rr}_{\mathrm{d}}$ increases by about $3 \mathrm{EJ} /$ day to $25 \mathrm{EJ} /$ day.

In the face of evidence of the progressive global warming of the Earth's climate, forming of arable lands under 
conventional tillage with the lowest possible roughness is one of the actions against this warming. We do not have sufficient competence to assess whether the amount of anticipated shortwave radiation absorbed and reflected from bare arable soils (depending on their roughness being the result of agricultural practices), with changing areas throughout the year, could have a noticeable impact on the climate on a global scale. Perhaps, the results of this first approximation may be interesting for climatologists who are able to reliably assess this factor.

Acknowledgements This work was supported by the Polish National Science Centre as part of the framework of project no. 2014/13/B/ ST10/02111.

Open Access This article is distributed under the terms of the Creative Commons Attribution 4.0 International License (http://creativeco mmons.org/licenses/by/4.0/), which permits unrestricted use, distribution, and reproduction in any medium, provided you give appropriate credit to the original author(s) and the source, provide a link to the Creative Commons license, and indicate if changes were made.

\section{References}

Allen RG, Pereira LS, Raes D, Smith M (1998) Crop evapotranspiration: guidelines for computing crop requirements. FAO irrigation drainage paper no 56, p 300

Baumgardner MF, Silva LF, Biehl LL, Stoner ER (1986) Reflectance properties of soils. Adv Agron 38:1-44

Ben-Dor E, Goldlshleger N, Benyamini Y, Agassi MR, Blumberg DG (2003) The spectral reflectance properties of soil structural crusts in the 1.2 to $2.5 \mu \mathrm{m}$ spectral region. Soil Sci Soc Am J 67:289-299

Ben-Gai T, Bitan A, Manes A, Alpert P, Rubin S (1998) Spatial and temporal changes in rainfall frequency distribution patterns in Israel. Theor Appl Climatol 61:177-190

Boiffin J (1986) Stages and time-depedency of soil crusting in situ. In: Callebaut F, Gabriels D, De Boodt M (eds) Assessment of soil surface sealing and crusting. Flanders Research Center for Soil Erosion and Soil Conservation, Ghent, pp 91-98

Bowers SA, Hanks RJ (1965) Reflection of radiant energy from soils. Soil Sci 100:130-138

Cierniewski J (1993) Soil moisture tension and soil spectra reflectance on the example of Koscian plain soils. Fotointerpr Geogr 23:107-122

Cierniewski J, Karnieli A, Kaźmierowski C, Ceglarek J (2014) A tool for predicting diurnal soil albedo variation in Poland and Israel. In: EARSeL eProceedings, special issue: 34th EARSeL symposium, pp 36-40

Cierniewski J, Karnieli A, Kaźmierowski C, Królewicz S, Piekarczyk J, Lewińska K, Goldberg A, Wesołowski R, Orzechowski M (2015) Effects of soil surface irregularities on the diurnal soil broadband blue-sky albedo variation. IEEE J Sel Top Appl Earth Obs Remote Sens 28:493-502

Cierniewski J, Królewicz S, Kaźmierowski C (2017) Annual dynamics of shortwave radiation as consequence of smoothing of previously plowed and harrowed soils in Poland. J Appl Meteorol Climatol 56:735-743

Cierniewski J, Ceglarek J, Kaźmierowski C (2018a) Estimating the diurnal blue-sky albedo of soils with given roughness using their laboratory reflectance spectra. J Quant Spectrosc Radiat Transf 217:213-223

Cierniewski J, Ceglarek J, Karnieli A, Ben-Dor E, Królewicz S, Kaźmierowski C (2018b) Shortwave radiation affected by agricultural practices. Remote Sens 10:419-429

Cierniewski J, Ceglarek J, Kaźmierowski C, Roujean J-L (2018c) Combined use of remote sensing and geostatistical datasets for estimating the dynamics of shortwave radiation of bare arable soils in Europe. Int J Remote Sens Spec Issue. https://doi. org/10.1080/01431161.2018.1474530

Coulson KL, Reynolds DW (1971) The spectral reflectance of natural surfaces. J Appl Meteorol 10:1285-1295

Davin EL, de Noblet-Ducoudré N, Friedlingstein P (2007) Impact of land cover change on surface climate: relevance of the radiative forcing concept. Geophys Res Lett 34:L13702. https://doi. org/10.1029/2007GL029678

De Jong SM, Addink EA, van Beek LPH, Duijsings D (2011) Physical characterization, spectra response and remotely sensed mapping of Mediterranean soil surface crust. Catena 86:24-35

Dexter R (2004) Diurnal and seasonal albedo trends of wheat at the Bratt's Lake observatory, Saskatchewan. Dissertation, Simon Fraser University

Dobos E (2017) Albedo. In: Lal R (ed) Encyclopedia of soil science, 3rd edn. Taylor \& Francis, Boca Raton, pp 89-91

Eshel G, Levy GJ, Singer MJ (2004) Spectral reflectance properties of crusted soils under solar illumination. Soil Sci Soc Am J 68:1982-1991

FAO/UNESCO (2007) Digital soil map of the world. 'FAO-UNLand and Water Division. http://www.fao.org/geonetwork/srv/ en/metadata.show?id=14116. Accessed 20 Jun 2017

Gilley JE, Kottwitz ER (1995) Random roughness assessment by the pin and chain method. Appl Eng Agric 12:39-43

Gilliot JM, Vaudour E, Michelin J (2017) Soil surface roughness measurement: a new fully automatic photogrammetric approach applied to agricultural bare fields. Comput Electron Agric 134:63-78

GlobCover (2009) Global land cover map. European Space Agency, Paris

Goldshleger N, Ben-Dor E, Benyamini Y, Agassi M, Blumberg DG (2001) Characterization of soil's structural crust by spectral reflectance in the SWIR region (1.2-2.5 $\mu \mathrm{m})$. Terra Nova 13:12-17

Goldshleger N, Ben-Dor E, Benyamini Y, Agassi M (2004) Soil reflectance as a tool for assessing physical crust arrangement of four typical soils in Israel. Soil Sci 169:677-687

Grant IF, Prata AJ, Cechet RP (2000) The impact of the diurnal variation of albedo on the remote sensing of the daily mean albedo of grassland. J Appl Meteorol 39:231-244

Heng BCP, Chandler JH, Armstrong A (2010) Applying close range digital photogrammetry in soil erosion studies. Photogramm Rec 25:240-265

Idso SB, Jackson RD, Reginato RJ, Kimball BA, Nakayama FS (1975) The dependence of bare soil albedo on soil water content. J Appl Meteorol 14:109-113

Kondratyev KY (1969) Radiacjonnyje Charakteristiki Atmosfery i Zemnoy Powerchnosti. Gidrometeorologiczeskoye Izdatelstwo Leningrad (in Russian)

Kondratyev KY, Fedchenko PP (1980) Vlijanije obrabotki na spektralnye otrazatelnye svojstva pochvy. Pochvoved 12:47-53 (in Russian)

König M, Tjemkes S, Kerkmann J (2001) Atmospheric instability parameters derived from MSG SEVIRI observations. Preprints. In: 11th Conference on satellite meteorology and oceanography, American Meteor Society, Madison, WI, pp 336-338

Lee C (2011) Corn growth stages and growing degree days: a quick reference guide cooperative extension service. University of Kentucky, Lexington 
Martonchik JV, Brugge CJ, Strahler A (2000) A review of reflectance nomenclature used in remote sensing. Remote Sens Environ 19:9-20

Marzahn P, Rieke-Zapp D, Ludwig R (2012) Assessment of soil surface roughness statistics for microwave remote sensing applications using a simple photogrammetric acquisition system. ISPRS J Photogramm Remote Sens 72:80-89

Mikhaylova NA, Orlov DS (1986) Opticheskie svoystva pochv i pochvennych komponentov. Nauka, Moskva (in Russian)

Miller P, Lanier W, Brandt S (2001) Using growing degree days to predict plant stages. Montana State University Extension Service 9, MT00103 AG 7

Monfreda C, Ramankutty N, Foley JA (2008) Farming the planet: 2. Geographic distribution of crop areas, yields, physiological types, and net primary production in the year 2000. Glob Biogeochem Cycles 22(1):1-19. https://doi.org/10.1029/2007GB002947

Monteith JL, Szeice G (1961) Modeling of surface solar irradiance for satellite applications on a global scale. J Appl Meteorol 31:194-211

Music HB, Pelletier RE (1986) Response of some Thematic Mapper band rations to variation in soil water content. Photogramm Eng Remote Sens 52:1661-1668

Obukhov AI, Orlov DS (1964) Spektralnaja otrazatelnaja sposobnost glavneysych tipov pochv i vozmoznost ispolzovaniya diffuznogo otrazenija pri pochvennych issledovanijach. Pochvoved 28:83-94 (in Russian)

Oguntunde PG, Ajayi AE, van de Giesen N (2006) Tillage and surface moisture effects on bare soil albedo of a tropical loamy sand. Soil Tillage Res 85:107-114

Oke TR (1987) Boundry layer climates, 2nd edn. Taylor \& Francis, Boca Raton

Orlov DS (1966) Kalichestvennye zakony otrazenija sveta ot pochvy. Vlijanie razmera chasti na otrazeniye. Nauch Dokl Vys Skoly Biol Nauki 4:206-210 (in Russian)

Oxford English Dictionary (2013) 3rd edn. Oxford University Press, Oxford

Piech KR, Walker JE (1974) Interpretation of soils. Photogramm Eng 40:87-94

Pinty B, Verstraette MM, Dickinson RE (1989) A physical model for predicting bidirectional reflectance over bare soil. Remote Sens Environ 27:273-288

Rechid D, Jacob D, Hagemann S, Raddatz TJ (2005) Vegetation effect on land surface albedo: method to separate vegetation albedo from the underlying surface using satellite data. Geophys Res Abstr 7:07153
Rieke-Zapp DH, Nearing MA (2005) Digital close range photogrammetry for measurement of soil erosion. Photogramm Rec 20:69-87

Roxy MS, Sumithranand VB, Renuka G (2010) Variability of soil moisture and its relationship with surface albedo and soil thermal diffusivity at Astronomical Observatory, Thiruvananthapuram, south Kerala. J Earth Syst Sci 119:507-517

Sacks WJ, Deryng D, Foley JA, Ramankutty N (2010) Crop planting dates: an analysis of global patterns. Glob Ecol Biogeogr 19:607620. https://doi.org/10.1111/j.1466-8238.2010.00551.x

Schaepman-Strub G, Schaepman ME, Painter TH, Dangel S, Martonchik JV (2006) Reflectance quantities in optical remote sensing: definitions and case studies. Remote Sens Environ 103:27-42

Schneider SH, Dickinson RE (1974) Climate modeling. Rev Geophys 12:447-493

Sellers PJ, Meeson BW,. Hall FG, Asrar G,. Murphy RE,. Schiffer RA FP, Bretherton FP, Dickinson RE, Ellingson RG, Field CB, Huemmrich KF, Justice CO, Melack JM, Roulet NT, Schimel DS, Try PD (1995) Remote sensing of the land surface for studies of global change: models - algorithms - experiments. Remote Sens Environ 51:3-26. https://doi.org/10.1016/0034-4257(94)00061-Q

Song J (1999) Phenological influences on the albedo of prairie grassland and crop fields. Int J Biometeorol 42:153-157

Taconet OV, Ciarletti V (2007) Estimating soil roughness indices on a ridgeand-furrow surface using stereo photogrammetry. Soil Tillage Res 93:64-76

Thomsen LM, Baartman JEM, Barneveld RJ, Starkloff T, Stolte J (2015) Soil surface roughness: comparing old and new measuring methods and application in a soil erosion model. Soil 1:399-410

Ulaby FT, Moore RK, Fung AK (1982) Microwave remote sensing active and passive. Addison-Wesley, Reading

USDA (1994) Major world crop areas and climatic profiles. In: Agricultural handbook. World agricultural outlook board, United States Department of Agriculture, Washington

Vinogradov BV (1983) Quantitative expression of function indicated soil moisture by remote sensing. Dokl Akad Nauk SSR 272:247-250

Worthington C, Hutchinson C (2005) Accumulated growing degree days as a model to determine key developmental stages and evaluate yield and quality of potato. In: Proceedings of the Florida state horticultural society, vol 1, pp 98-101

Publisher's Note Springer Nature remains neutral with regard to jurisdictional claims in published maps and institutional affiliations. 